\title{
METODE PENDIDIKAN TAUHID DALAM KISAH IBRĀHĪM AS. DAN IMPLIKASINYA TERHADAP PEMBELAJARAN PAI DI SEKOLAH
}

\author{
Hilma Fauzia Ulfa,* Aam Abdussalam, Cucu Surahman \\ Universitas Pendidikan Indonesia \\ *E-mail: bilmabilwab@gmail.com
}

\begin{abstract}
This study discusses the method of taubid (monotheism) education conducted by Prophet Ibrähim a.s. to his family and followers. By using thematic method (maudiu'i) of Qur'anic interpretation, the authors try to dig methods or ways to imprint monotheistic values (taubid) based on the story of Prophet Ibrähim a.s. in the Qur'an. The primary data used in this study are the Al-Qur'an and 5 (five) books of tafsīr (tafsīr al-Mișbāh, tafsīr al-Maragi, tafsīr Fī Zilāl Alqurān, tafsīr alAzhār, and tafsīr al-Muyassar); and secondary data are obtained from books and scientific paper related to the discussion. The results of this study shows that there are some methods used by Prophet Ibrähim a.s. in conveying his teaching of monotheism, those are: intuitive method, rational method, Targīb wa Tarhīb method, Ibrah Mau'iẓah method, scientific method, Hiwār Jadali method, demonstration / eksperimental method, and example method. These methods have implication to the development of PAI (Islamic Religious Education, IRE) learning methods in school, especially those related to the learning of monotheism.
\end{abstract}

Keywords: Ibrabim, Method of Taubid Education, Islamic Religious Education learning.

\begin{abstract}
ABSTRAK
Penelitian ini membahas tentang metode pendidikan taubid yang dilakukan Nabi Ibrabim As. dalam menghadapi keluarga dan kaumnya. Dengan menggunakan metode tafsir maudì'i, penulis berusaba menggali metode atau cara menanamkan nilai-nilai taubid berdasarkan cerita Nabi Ibrähim As. dalam al-Qur'an. Data primer yang digunakan dalam penelitian ini adalab Alquran dan 5 kitab tafsīr (tafsīr al-Mișbāh, tafsīr al-Maragi, tafsīr Fī Zilāl Alquran, tafsīr alAzhar, dan tafsir al-Muyassar); dan data sekunder diperoleh dari buku-buku dan karya tulis ilmiah yang berkaitan dengan pembahasan. Hasil penelitian ini menunjukekan bahwa terdapat beberapa metode yang digunakan oleh Nabi Ibräbim As. dalam menyampaikan ajaran taubidnya, di antaranya: metode intuitif, metode rasional, metode Targib wa Tarhib, metode Ibrah Maw'izah, metode ilmiah, metode Hiwār Jadali, metode demonstrasi / ekesperimen, dan metode keteladanan. Metode-metode tersebut memiliki implikasi terhadap pengembangan metode pembelajaran PAI (Pendidikan Agama Islam) di sekolah, khususnya pembelajaran taubid.
\end{abstract}

Kata Kunci: Ibrabim, Metode Pendidikan Taubid, Pembelajaran PAI.

TARBAWY: Indonesian Journal of Islamic Education - Vol. 4 No. 2 (2017) | 80 


\section{PENDAHULUAN}

Pada dasarnya setiap manusia memiliki fitrah berupa kepercayaan terhadap adanya Tuhan. Fitrah manusia tersebut merupakan fitrah beragama tauhid yang Allah berikan kepada manusia itu pada saat ia diciptakan. Tauhid adalah pegangan pokok yang sangat menentukan bagi kehidupan manusia. Tauhid juga merupakan landasan bagi setiap amal yang dilakukan oleh hambanya. Setiap amal yang tidak dilandasi dengan tauhid akan sia-sia, tidak dikabulkan oleh Allah dan terlebih jika amal yang dikerjakan itu dilandasi dengan syirik akan menyengsarakannya di dunia dan di akhirat. Dan dalam pandangan islam tauhidlah yang akang menghantarkan manusia kepada kehidupan yang baik di dunia dan kebahagiaan yang hakiki di alam akhirat nanti.

Tauhid juga merupakan risalah utama yang diemban para Nabi sejak Adam hingga Nabi Muhammad Saw., untuk disampaikan kepada umatnya. Salah seorang Nabi yang banyak diceritakan berkaitan dengan ajaran tauhidnya adalah Nabi Ibrāhīm As.

Nabi Ibrāhīm As,, menurut Țahir Ibn 'Asyūr diperkirakan lahir pada 2893 sebelum Hijrah dan meninggal dunia pada 2818 sebelum Hijrah serta dimakamkan di kota alKhalīl Palestina. Beliau diberi gelar Bapak para nabi karena banyak sekali nabi yang merupakan anak cucunya. Beliau juga diberi gelar Pengumandang Taubid karena dengan pengalaman ruhani dan pengembaraan akliahnya beliau "menemukan" dan mengumandangkan bahwa Allah adalah Tuhan Yang Maha Esa serta
Tuhan seru sekalian alam, sedang sebelumnya para nabi memperkenalkan Tuhan-kepada kaumnya - sebagai Tuhan mereka saja, tanpa memperluasnya menjadi Tuhan seru sekalian alam (Shihab, 2002, hal. 73-74).

Dalam misi menyebarkan ajaran tauhid yang dilakukannya tersebut tentu tidaklah mudah, Nabi Ibrāhīm As. mendapatkan ujian dan cobaan dari kaumnya yang tidak mau menerima ajaran yang dibawanya. Oleh karena itu, Nabi yang diutus oleh Allah untuk menyampaikan/risalah atau ajaran tauhid itu dituntut untuk memiliki kecerdasan dalam cara atau metode penyampaian misi mereka agar dapat direspon, diterima dan diamalkan dengan baik oleh mereka.

Berdasarkan hal tersebut, metode atau pendekatan yang dilakukan Nabi Ibrāhīm As. tersebut dirasa perlu dikaji secara lebih mendalam sebagai upaya memahami akidah dan solusi dari berbagai masalah penyimpangan-penyimpangan akidah dan moral yang dihadapi masyarakat Indonesia saat ini pada umumnya, utamanya dalam upaya melahirkan generasi insān kamīl di masa depan. Fokus penelitian ini meliputi metode pendidikan tauhid yang dilakukan Nabi Ibrāhīm As. dan implikasinya terhadap pembelajaran PAI di sekolah.

\section{METODE PENELITIAN}

Metode penelitian yang digunakan dalam penelitian ini adalah studi kepustakaan (library research) dengan pendekatan kualitatif. Penelitian ini merupakan studi Qur'an 
sehingga metode yang digunakan pun menggunakan metode Alquran, yaitu metode tafsir. Adapun metode tafsir yang digunakan dalam penelitian ini adalah metode tafsir mawdù

Instrumen dari penelitian ini adalah peneliti sendiri yang berusaha mengumpulkan data sebanyakbanyaknya dari sumber utama yaitu Alquran dan sumber sekunder yaitu 5 kitab tafsir, buku-buku referensi serta karya tulis ilmiah lainnya yang menunjang pembahasan penelitian ini.

Untuk menentukan ayat yang akan digunakan dalam penulisan ini, penulis berangkat dengan mencari kata dasar Ibrāhīm dalam Alquran menggunakan bantuan kitab AlMu’jam Al-Mufahras li Al-Alfāz AlQur’ān Al-Karīm karya Muhammad Fu'ad Abd al-Baqy(1407 H/1987 M). Nama Ibrāhīm disebut dalam Alquran sebanyak 69 kali pada 63 ayat dan menjadi nama surat ke-14. Diantaranya penyebutan terbanyak terdapat dalam surat Al-Baqarah sebanyak 12 kali, surat Ali Imrān sebanyak 7 kali, surat Al-An'ām, surat Hūd, dan Al-Anbiyā sebanyak 4 kali, dan pada surat Aș-Sāffāt dan Al-Hajj sebanyak 3 kali (Miftahul Huda, 2008, hlm. 146-147).

Dengan jumlah ayat yang cukup banyak ini, tentunya penulis mendapatkan kesulitan apabila diharuskan untuk mengkaji secara mendalam seluruh ayat tersebut. Oleh karena itu, penulis menyeleksi dan membatasi ayat-ayat tersebut sehingga hanya beberapa ayat saja yang dipilih untuk dibahas dalam penulisan. Selanjutnya, ayat yang sudah dipilih tersebut dikaji secara mendalam.
Adapun batasannya adalah ayatayat yang secara tersirat membahas metode pendidikan tauhid di dalam kisah Nabi Ibrāhīm as. Dengan batasan tersebut, akhirnya penulis mendapatkan beberapa ayat yang akan dikaji dalam pembahasan ini.

Sebelum membahas ayat-ayat tersebut, penulis akan membahas sejarah hidup nabi Ibrāhīm as terlebih dahulu. Dengan mengetahui sejarah tersebut, diharapkan dapat mempermudah penulis menganalisis dan memahami ayat-ayat tersebut.

\section{HASIL PENELITIAN DAN PEMBAHASAN}

Ibrāhīm as adalah keturunan kesepuluh dari Nūh as. yang lahir melalui Sam. Silsilah lengkapnya adalah Ibrāhìm as ibn Tarih atau Āzar, ibn Nahur ibn Saruj ibn Ra'u ibn Falij ibn Abir ibn Syalih ibn Arfaksyad (atau Arfakhsyadz) ibn Sam ibn Nūḥ as (Harahap, 2013, hlm. 39).

Ibrāhīm (1997-1822 SM) merupakan Nabi dan Rasul dalam agama samawi. Ia mendapat gelar sebagai khalil Allah (sahabat Allah). Selain itu ia bersama anaknya, Ismā̄̄ll terkenal sebagai pengasa Ka ${ }^{`}$ bah. Ia diangkat sebagai Nabi sekitar 1900 SM, diutus untuk kaum Kaldan yang terletak di kota Ur, negeri yang disebut kini Iraq. Ibrāhīm dikenal sebagai salah satu Nabi ülul 'azmi. Ibrāhīm ibn Āzar ibn Tahur ibn Sarush, dilahirkan di sebuah tempat bernama Faddam, A ‘ram yang terletak dikawsan kerajaan Babilonia. Ia memiliki dua orang putra yang dikemudian hari menjadi Nabi pula, yaitu Ismāầl dan Isḥāq (Siddik, 2012). 
Terkait kelahiran Ibrāhīm as., pendapat terkuat menunjukkan bahwa ia lahir di Kota Ur pada sekitar tahun 1978 SM. Taurat menyebut kota kelahiran Ibrāhīm as. Dengan Ur Kaldan. Kota ini berada di tepi selatan sungai Furat, sekitar 150 kilometer sebelah barat Bashrah (Harahap, 2013, hlm. 48).

Al-Khāṭib al-Bagdādī menyampaikan riwayat dari Ibn 'Abbās bahwa pertumbuhan tubuh bayi Ibrāhīm as. dalam sehari sama dengan seminggu, seminggu sama dengan sebulan, dan sebulan sama dengan setahun. Jika telat menyusui atau ketika air susunya mongering, Ahilah (ibu Nabi Ibrāhīm as.) sering kali menemukan Ibrāhīm as. mengisap ibu jarinya sendiri. Dari ibu jarinya itu, air susu dan madu memancar. Sejak saat itulah bayi-bayi manusia sering mengisap ibu jarinya hingga zaman sekarang (Harahap, 2013, hlm. 48).

Menurut Rusdi al-Badrawi (Harahap, 2013, hlm. 56-57) tidak ada satu pun riwayat shahih yang menerangkan pada usia berapa Ibrāhīm as. Diangkat sebagai nabi. Perkiraan waktu pengangkatannya menjadi nabi hanya dapat disimpulkan berdasarkan kaidah umum yang menegaskan bahwa seseorang diangkat Allah Swt. sebagai nabi hanya ketika betul-betul telah dewasa dan usianya telah mencapai empat puluh tahun.

Pada masa Nabi Ibrāhīm, kebanyakan rakyat di Mesopotamia beragama politeisme. Dewa Sin (dewa bulan) merupakan salah satu berhala yang palin penting. Bintang, bulan dan matahari menjadi obyek utama penyembahan. Ibrāhīm menyaksikan dan mengalami kesesatan kaumnya tersebut sehingga dia berusaha lebih dulu memertebal keimanan dn keyakinannya dengan pencariannya terhadap tuhan yang sebanarnya. Hal ini dapat dilihat dalam QS al-An`ām: 74-79 (Siddik, 2012).

Allah Swt. telah memilih Ibrāhīm as. Sebagai nabi dan rasul-Nya dengan tugas suci mengeluarkan kaumnya dari kesesatan. Keluarganya sendiri adalah pihak pertama yang diserunya. Āzar atau Tarih, ayahnya diajaknya beriman kepada Allah Swt. dengan lembut. Ajakan Ibrāhīm as. tidak disambut baik oleh ayahnya sebagaimana yang diharapkan. Ia pun menyeru kaumnya, mengingatkan mereka bahwa patung-patung berhala itu tida dapat mendengar, memberi manfaat, atau membahayakan mereka sedikit pun. Namun, jawaban mereka tidak seperti yang diharapkannya (Harahap, 2013, hlm. 57).

Satu riwayat mengatakan bahwa Āzar adalah paman Nabi Ibrāhīm as., mengingat dalam budaya Arab paman dianggap sebagai ayah. Āzar termasuk penduduk kusa, sebuah desa di bagian kota Kufah. Tempat kelahirannya adalah Kusa, atau Babylon, atau AlWarka. Di kota itu pulalah Nabi Ibrāhīm as pernah dibakar. Setelah selamat dari upaya pembakaran terhadap dirinya, Nabi Ibrāhīm as kemudian bertolak menuju Haran sebuah tempat di utara Semenanjung Arabia. Kemudian Ia melanjutkan perjalanan ke Palestina bersama Istri (Sarah), keponakan dan istri keponakan (Lūṭ dan Istri). Karena daerah Palestina tertimpa kekeringan dan kelaparan, akhirnya Ia pindah ke 
Mesir pada masa kekuasaan raja-raja pengembara (Hexus) (Al-Syarif \& Manshur, 2017, hlm. 2).

Nabi Ibrāhīm as kembali ke daerah selatan Palestina bersama Nabi Luț as. Demi menjaga keutuhan hubungan kekerabatan dan supaya bisa menggembalakan ternak masingmasing, akhirnya keduanya berpisah. Nabi Ibrāhīm as tinggal di Birr Siba, sementara Nabi Luț as tinggal di bagian selatan laut Mati yang kemudian dikenal dengan nama "Buhairah Lūț". Lalu Nabi Ibrāhīm as pergi ke Mekah bersama istri keduanya, Hajar, dan putranya, Nabi Ismā'īl as. setelah Ia meninggalkan keduanya (Hajar dan Ismā̄̄ll) dilembah yang gersang dan setelah air zamzam ditemukan dengan airnya yang deras, datanglah suku Jurhum dari arah lembah Kada. Ketika Nabi Ibrāhīm as meningal dunia, ia dimakamkan dikota Al-Khalil (Hebron), Palestina (AlSyarif \& Manshur, 2017, hlm. 2).

Tauhid berasal dari bahasa arab, masdar dari kata waḥhada - yuwahhịidu. Secara etimologis, Tauhid berarti keesaan. Maksudnya, I'tikad atau keyakinan bahwa Allah SWT adalah Esa; tunggal; satu. Pengertian ini sejalan dengan pengertian Tauhid yang digunakan dalam bahasa Indonesia, yaitu "keesaan Allah"; mentauhidkan berarti "mengakui keesaan Allah; mengesakan Allah" (Asmuni, 1993, hlm. 1). Arti Tauhid ialah percaya dan yakin tentang wujud Tuhan Yang Esa, Yang tidak ada sekutu bagi-Nya, baik berupa dzat, sifat maupun perbuatanNya; Yang mengutus utusan-utusanNya untuk memberi petunjuk kepada alam dan umat manusia kepada jalan kebaikan; Yang meminta pertanggung jawaban seseorang di akhirat dan memberikan balasan kepadanya atas apa yang telah diperbuatnya selama di dunia ini, baik ataukah buruk (Hanafi, 1995, hlm. 12).

Berdasarkan beberapa pengertian di atas, dapat disimpulkan bahwa yang dimaksud dengan Tauhid adalah keyakinan kepada kemahaesaan Allah, baik dari dzat, sifat maupun perbuatan-Nya, juga meyakini tentang rasul-rasul Allah dan masalah apapun yang berkaitan dengannya.

Adapun pendidikan tauhid ialah pemberian bimbingan kepada anak didik agar ia memiliki jiwa tauhid yang kuat dan mantap dan memiliki tauhid yang baik dan benar. Bimbingan itu dilakukan tidak hanya dengan lisan dan tulisan, tetapi juga-bahkan ini yang terpenting-dengan sikap, tingkah laku dan perbuatan. Sedangkan yang dimaksud dengan pengajaran tauhid ialah pemberian pengertian tentang ketauhidan, baik sebagai akidah yang wajib diyakini maupun sebagai filsafat hidup yang membawa kepada kebahagiaan hidup duniawi dan ukhrawi (Asmuni, 1993, hlm. 41-42). Pendidikan tauhid mempunyai tujuan agar manusia memiliki keyakinan yang kuat terhadap Allah serta dapat menjadi Muslim yang käffah.

Adapun menurut Mahmud Yunus seperti yang disebutkan dalam Constantin (2012, hlm. 100) menyatakan bahwa tujuan pendidikan dalam bidang keimanan ialah :

a. Agar memiliki keimanan yang teguh kepada Allah, Rasul-rasul, Malaikat, hari akhir, dan lain sebagainya. 
b. Agar memiliki keimanan berdasarkan kepada kesadaran dan ilmu pengetahuan, bukan sebagai "pengikut buta" atau taklid semata- mata.

c. Agar keimanan itu tidak mudah rusak apalagi diragukan oleh orang- orang yang tidak beriman.

Usaha-usaha pemupukan rasa keimanan pada anak harus sungguhsungguh mendapat perhatian setiap orang tua, guru atau pengasuh anak agar keimanan itu tumbuh dan berkembang secara wajar. Usaha tersebut dapat dilakukan melalui tiga proses: Pembiasaan, pembentukan pengertian, dan akhirnya pembentukan budi luhur (Asmuni, 1993, hlm. 43).

Sementara, Ibrāhīm As. adalah keturunan kesepuluh dari Nūh As. yang lahir melalui Sam. Silsilah lengkapnya adalah Ibrāhīm As. ibn Tarih atau Āzar, ibn Nahur ibn Saruj ibn Ra'u ibn Falij ibn 'Abir ibn Syalih ibn Arfaksyad (atau Arfakhsyadz) ibn Sam ibn Nūh As. (Harahap, 2013, hlm. 39).

Terkait kelahiran Ibrāhīm As., pendapat terkuat menunjukkan bahwa ia lahir di Kota Ur pada sekitar tahun 1978 SM. Taurat menyebut kota kelahiran Ibrāhīm As. Dengan Ur Kaldan. Kota ini berada di tepi selatan sungai Furat, sekitar 150 kilometer sebelah barat Bashrah (Harahap, 2013, hlm. 48).

Allah Swt. telah memilih Ibrāhīm As. Sebagai nabi dan rasulNya dengan tugas suci mengeluarkan kaumnya dari kesesatan. Keluarganya sendiri adalah pihak pertama yang diserunya. Āzar atau Tarih, ayahnya diajaknya beriman kepada Allah Swt. dengan lembut. Ajakan Ibrāhīm As. tidak disambut baik oleh ayahnya sebagaimana yang diharapkan. Ia pun menyeru kaumnya, mengingatkan mereka bahwa patung-patung berhala itu tida dapat mendengar, memberi manfaat, atau membahayakan mereka sedikit pun. Namun, jawaban mereka tidak seperti yang diharapkannya (Harahap, 2013, hlm. 57).

Satu riwayat mengatakan bahwa Āzar adalah paman Nabi Ibrāhīm As., mengingat dalam budaya Arab paman dianggap sebagai ayah. Āzar termasuk penduduk kusa, sebuah desa di bagian kota Kufah. Tempat kelahirannya adalah Kusa, atau Babylon, atau AlWarka. Di kota itu pulalah Nabi Ibrāhīm As. pernah dibakar. Setelah selamat dari upaya pembakaran terhadap dirinya, Nabi Ibrāhīm As. kemudian bertolak menuju Haran sebuah tempat di utara Semenanjung Arabia. Kemudian Ia melanjutkan perjalanan ke Palestina bersama Istri (Sarah), keponakan dan istri keponakan (Lūṭ dan Istri). Karena daerah Palestina tertimpa kekeringan dan kelaparan, akhirnya Ia pindah ke Mesir pada masa kekuasaan raja-raja pengembara (Hexus) (Al-Syarif \& Manshur, 2017, hlm. 2).

Nabi Ibrāhīm As. kembali ke daerah selatan Palestina bersama Nabi Lūt As. Demi menjaga keutuhan hubungan kekerabatan dan supaya bisa menggembalakan ternak masingmasing, akhirnya keduanya berpisah. Nabi Ibrāhīm As. tinggal di Birr Siba, sementara Nabi Lūṭ As. tinggal di bagian selatan laut Mati yang kemudian dikenal dengan nama "Buhairah Lūṭ". Lalu Nabi Ibrāhīm As. 
pergi ke Mekah bersama istri keduanya, Hajar, dan putranya, Nabi Ismā’il As. setelah Ia meninggalkan keduanya (Hajar dan Ismā̄ill) dilembah yang gersang dan setelah air zamzam ditemukan dengan airnya yang deras, datanglah suku Jurhum dari arah lembah Kada. Ketika Nabi Ibrāhīm As. meningal dunia, ia dimakamkan dikota Al-Khalil (Hebron), Palestina (AlSyarif \& Manshur, 2017, hlm. 2).

Terkait dengan Pendidikan agama Islam (PAI), di dalam UUSPN No. 2/ 1989 pasal 39 ayat (2) ditegaskan bahwa isi kurikulum setiap jenis, jalur dan jenjang pendidikan wajib memuat, antara lain pendidikan agama. Dan dalam penjelasannya dinyatakan bahwa pendidikan agama merupakan usaha untuk memperkuat iman dan ketakwaan terhadap Tuhan Yang Mahaesa sesuai dengan agama yang dianut oleh peserta didik yang bersangkutan dengan memperhatikan tuntutan untuk menghormati agama lain dalam hubungan kerukunan antar umat beragama dalam masyarakat untuk mewujudkan persatuan nasional (Muhaimin, Suti'ah, \& Ali, 2001, hlm. 75).

Menurut Daradjat (2004, hlm. 86) Pendidikan agama Islam adalah pendidikan dengan melalui ajaranajaran agama Islam, yaitu berupa bimbingan dan asuhan terhadap anak didik agar nantinya setelah selesai dari pendidikan ia dapat memahami, menghayati dan mengamalkan ajaranajaran agama Islam yang telah diyakininya secara menyeluruh, serta menjadikan ajaran agama Islam itu sebagai suatu pandangan hidupnya demi keselamatan dan kesejahteraan hidup di dunia maupun di akhirat kelak.

Selanjutnya, Majid (2012, hlm. 12) mengutip pengertian Pendidikan Agama Islam menurut Tayar Yusuf (1986) yang mengartikan pendidikan agama Islam sebagai usaha sadar generasi tua untuk mengalihkan pengalaman, pengetahuan, kecakapan dan keterampilan kepada generasi muda agar kelak menjadi muslim, bertakwa kepada Allah Swt, berbudi pekerti luhur, dan berkepribadian yang memahami, menghayati dan mengamalkan ajaran agama Islam dalam kehidupannya, sedangkan menurut Ahmad Tafsir, Pendidikan Agama Islam adalah bimbingan yang diberikan seseorang agar ia berkembang secara maksimal sesuai dengan ajaran Islam.

Berbagai pendapat para ahli mengenai pengertian Pendidikan Agama Islam (PAI) nampaknya sudah cukup jelas. Hemat penulis, yang dimaksud pendidikan agama Islam itu merupakan sebuah usaha atau salah satu aktifitas yang dilakukan oleh orang dewasa yang telah disusun terlebih dahulu dalam rangka mewujudkan tujuan dari pendidikan Islam yaitu menjadikan peserta didik tidak hanya mampu untuk mampu memahami ajaran agama namun yang terpenting ialah mampu melaksanakan dan menghayati ajaran agama Islam dalam kehidupan sehari-hari. Dan tujuan itu dapat dicapai melalui pembinaan dan pengajaran yang dilakukan secara terus menerus dan intensif.

Tujuan Pendidikan Agama Islam tidak terlepas dari tujuan nasional dari 
pendidikan yang diselenggarakan di Indonesia. Di dalam GBPP dijelaskan bahwa pendidikan agama Islam bertujuan untuk "meningkatkan keimanan, pemahaman, penghayatan, dan pengalaman peserta didik tentang agama Islam, sehingga menjadi manusia muslim yang beriman dan bertakwa kepada Allah Swt serta berakhlak mulia dalam kehidupan pribadi, bermasyarakat, berbangsa dan bernegara".

Penggunaan metode dalam suatu mata pelajaran bisa lebih dari satu macam. Metode yang variatif dapat membangkitkan motivasi belajar anak didik. Pemilihan dan penggunaan metode harus mempertimbangkan aspek efektifitas dan relevansinya dengan materi. Keberhasilan penggunaan suatu metode merupakan kunci keberhasilan proses pembelajaran, dan akhirnya menentukan kualitas pendidikan. Sehingga metode pendidikan Islam yang dikehendaki akan membawa kemajuan pada semua bidang ilmu pengetahuan dan keterampilan. Secara fungsional dapat merealisasikan nilainilai ideal yang terkandung dalam tujuan pendidikan Islam itu sendiri, dan ini tidak bertentangan dengan tujuan pendidikan nasional yang bertujuan membentuk manusia pancasilais yang bertaqwa kepada Tuhan Yang Maha Esa (Fikri, 2011, hlm. 118-119).

Beberapa pakar pendidikan Islam mengemukakan metode pendidikan yang digali dan dikembangankan berdasarkan ayatayat Alquran dan hadis, antara lain metode Hiwàr, Ibrah-Maw'izaah, Amsial,
Qișah, Tajribah, Targhib-Tarbib, dan Uswah Hasanah (Syahidin, 2009, hlm. 45).

Adapun metode yang digunakan Nabi Ibrāhīm As., berdasarkan temuan penulis, ditemukan dalam beberapa ayat Alquran yang berkaitan dengan kisah Nabi Ibrāhīm As., sebagai berikut.

\section{Metode Intuitif (Manhāj 'Aq)}

Metode intuitif, sesuai dengan namanya metode ini berkaitan dengan intuisi atau qalb (hati). Metode intuitif adalah adalah pengetahuan yang diperoleh secara tiba-tiba teranugerahkan langsung dari Allah Swt. (Al-Syarif \& Manshur, 2017, hlm. 3). Sebagaimana tercantum dalam QS. Maryam [19]: 41 dan 43

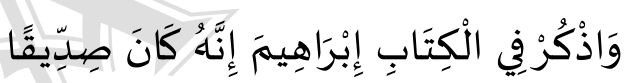<smiles>[AsH2]</smiles>

"Ceritakanlah (hai Muhammad) kisah Ibrāhīm di dalam Al kitab (Al Quran) ini. Sesungguhnya ia adalah seorang yang sangat membenarkan lagi seorang Nabi” (QS. Maryam [19]: 41).

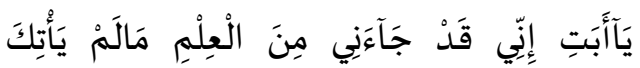

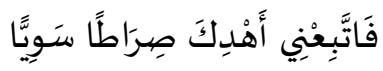

"Wahai bapakku, Sesungguhnya telah datang kepadaku sebahagian ilmu pengetahuan yang tidak datang kepadamu, Maka ikutilah Aku, niscaya aku akan menunjukkan kepadamu jalan yang lurus" (QS. Maryam [19]: 43).

Dari ayat tersebut, dapat dipahami bahwa Nabi Ibrāhīm As. diberikan ilmu oleh Allah yang tidak diberikan kepada orang lain atau bisa dikatakan sebagai 'ilm ladunnì atau bisa juga dikatakan sebagai metode intuitif. 
Metode intuitif ini tidak mengandalkan akal dan juga tidak pada indera seperti halnya metode ilmiah, melainkan lebih mengandalkan anugerah Tuhan yang diberikan kepada manusia dengan pencerahan pikiran, kendatipun diawali dengan proses berpikir (Qomar, 2005, hlm. 301).

Kemudian, dengan ilmu tersebut nabi berusaha untuk mengajak ayahnya agar mau mengikuti ajarannya tersebut, sehingga ayahnya dapat terbebas dari jalan setan (kemusyrikan) yang selama ini ditempuhnya. Namun, ayahnya tetap tidak mau mengikuti Nabi Ibrāhīm As.

\section{Metode Rasional}

Metode ini merupakan metode yang dipakai untuk memperoleh pengetahuan dengan menggunakan pertimbangan-pertimbangan atau kriteria-kriteria kebenaran yang bisa diterima rasio (Al-Syarif \& Manshur, 2017, hlm. 3).

Penulis menemukan bahwa salah satu metode yang dilakukan oleh Nabi Ibrāhīm As. dalam menyampaikan ajaran tauhidnya adalah dengan metode rasional yang dilakukan kepada ayahnya sendiri. Sebagaimana firman Allah dalam (QS. Maryam [19]:42-43) berikut.

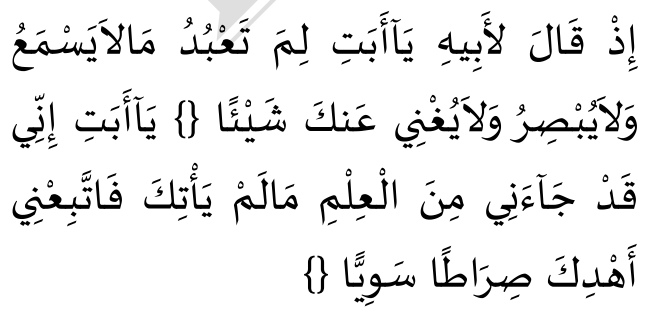

"Ingatlah ketika ia berkata kepada bapaknya; "Wahai bapakku, mengapa kamu menyembah sesuatu yang tidak mendengar, tidak melihat dan tidak dapat menolong kamu sedikitpun?
Wahai bapakku, Sesungguhnya telah datang kepadaku sebahagian ilmu pengetahuan yang tidak datang kepadamu, Maka ikutilah Aku, niscaya aku akan menunjukkan kepadamu jalan yang lurus"(QS. Maryam [19]:4243).

Dalam ayat tersebut diceritakan bahwa Nabi Ibrāhīm As. mengemukakan kesalahan bapaknya yang telah menjadikan berhala sebagai sesembahannya. Beliau mengajak bapaknya untuk menggunakan akalnya bahwa apa yang disembahnya selama ini tidak dapat memberi manfaat apapun kepada ayahnya.

Anjuran berpikir rasional terhadap makhluk-makhluk Allah atau alam semesta ini membuktikan bahwa petunjuk yang dibawa oleh Alquran kepada orang-orang yang bertakwa itu tidak sekedar melalui doktrin-doktrin yang begitu saja diterima apa adanya, tetapi justru melalui penalaran yang logis dan rasional. Penalaran ini dapat membantu seseorang untuk menerima petunjuk dari Allah. Dengan demikian, berarti Islam sesungguhnya mengehandaki terwujudnya masyarakat atau komunitas terpelajar yang memiliki tradisi berpikir rasional untuk mencapai pengetahuan baru (Qomar, 2005, hlm. 274).

Dapat disimpulkan bahwa berpikir rasional itu tidak mutlak kehendak akal tetapi juga anjuran wahyu yang berasal dari Alquran. Hal tersebut bertujuan agar manusia memaksimalkan potensi akal yang dimilikinya untuk memahami tandatanda kebesaran Allah sehingga semakin bertambah keyakinannya terhadap Allah. 


\section{Metode Targīb wa Tarhīb}

Abdurrahman an-Nahlawi dalam Sri Minarti (2013, hlm. 143) mendefinisikan metode targhib sebagai cara penyajian pembelajaran dalam konteks kebahagiaan hidup di akhirat. Targhib berarti janji Allah terhadap kesenangan dan kenikmatan akhirat yang disertai bujukan.

Penulis menemukan bahwa salah satu metode yang dilakukan oleh Nabi Ibrāhīm As. dalam menyampaikan ajaran tauhidnya adalah dengan metode Targib wa Tarbib yang dilakukan kepada ayahnya sendiri. Sebagaimana firman Allah dalam (QS. Maryam [19]:44-45).

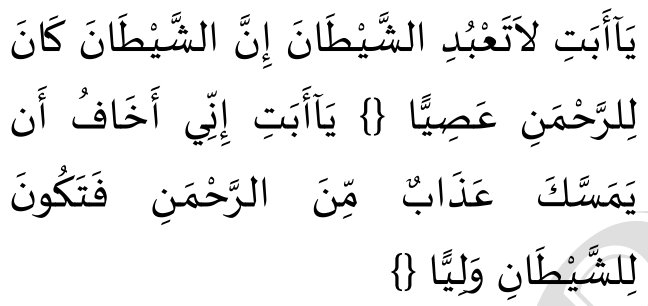

"Wahai bapakku, janganlah kamu menyembah syaitan. Sesungguhnya syaitan itu durhaka kepada Tuhan yang Maha Pemurah. Wahai bapakku, Sesungguhnya aku khawatir bahwa kamu akan ditimpa azab dari Tuhan yang Maha pemurah, maka kamu menjadi kawan bagi syaitan" (QS. Maryam [19]: 44-45).

Kelompok ayat di atas menceritakan tentang ayah Nabi Ibrāhīm As. yang menyembah berhala. Kemudian Nabi Ibrāhīm As. mengajak ayahnya untuk meninggalkan kesesatan tersebut kepada jalan kebenaran. Nabi Ibrāhīm As. juga mengemukakan akibat yang akan diterima ayahnya jika tetap tidak mau mengikuti ajakannya, namun ayahnya tetap menolak dengan penolakan yang kasar.
Dapat disimpulkan bahwa kedua ayat di atas merupakan salah satu cara yang dilakukan Nabi Ibrāhīm untuk menyampaikan ajaran tauhid kepada orang tuanya dengan tujuan agar orang tuanya itu takut dan termotivasi untuk berbuat kebaikan dan kembali ke jalan Allah sehingga selamat dari murkanya Allah.

\section{Metode 'Ibrah Maw'ịah}

Metode 'ibrah merupakan penyajian bahan pembelajaran yang bertujuan untuk melatih daya nalar peserta didik dalam menangkap makna terselubung dari suatu pernyataan atu kondisi psikis sehingga manusia sampai kepada intisari yang dimaksud (Minarti, 2013, hlm. 143).

Penulis menemukan bahwa salah satu metode yang dilakukan oleh Nabi Ibrāhīm As. dalam menyampaikan ajaran tauhidnya adalah dengan metode Ibrah Maw'izah yang dilakukan kepada ayahnya sendiri. Sebagaimana firman Allah dalam (QS. Maryam [19]:46-48).

قَالَ أَرَاغِبْ أَنَتَ عَنْ عَالِلهتِي يَآإِبْرَاهِيمُ لَئَنْ

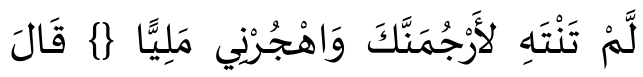

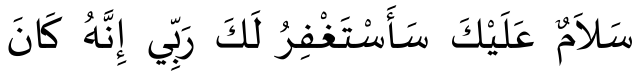

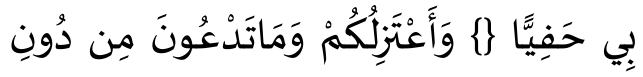

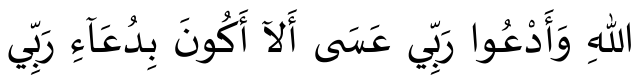

شَفِقِيَّا

"Berkata bapaknya: "Bencikah kamu kepada tuhan-tuhanku, Hai Ibrahim? jika kamu tidak berhenti, Maka niscaya kamu akan kurajam, dan tinggalkanlah aku buat waktu yang lama". Berkata Ibrahim: "Semoga keselamatan dilimpahkan kepadamu, aku akan memintakan ampun bagimu kepada Tuhanku. Sesungguhnya Dia sangat 
baik kepadaku. Dan aku akan menjauhkan diri darimu dan dari apa yang kamu seru selain Allah, dan aku akan berdoa kepada Tuhanku, Mudahmudahan aku tidak akan kecewa dengan berdoa kepada Tuhanku" (QS. Maryam [19]: 46-48).

Walaupun pada ayat sebelumnya yakni ayat 41-45, Nabi Ibrāhīm sudah menyampaikan pesan dan ajakannya dengan lemah lembut, dengan tutur kata yang paling baik dan paling indah tetapi tetap saja pesan itu tidak akan sampai kepada hati yang sudah rusak. Ayah Nabi Ibrāhīm tetap saja tak mau mengikuti ajakannya, bahkan ia membalasnya dengan ancaman dan kecaman siksaan.

Hemat penulis, Surat Maryam ayat 41-47 ini merupakan dakwah pertama yang dilakukan oleh Nabi Ibrāhīm As. dan dakwah tersebut dilakukan kepada bapaknya. Nabi Ibrāhīm As. terus menyeru ayahnya agar bertauhid kepada Allah dengan cara mengemukakan bukti-bukti kesesatannya dengan menyembah berhala serta memberinya peringatan dan nasihat.

\section{Metode Ilmiah}

Menurut Tafsir (2009, hlm. 10), metode ilmiah adalah cara menerapkan prinsip-prinsip logis terhadap penemuan, pengesahan dan penjelasan kebenaran. Juga dapat diartikan bahwa metode ilmiah adalah pengejaran terhadap sesuatu untuk memperoleh sesuatu interelasi.

Penulis menemukan bahwa metode ilmiah ini nyatanya sudah dilakukan sejak dulu oleh Nabi Ibrāhīm As. dalam menyampaikan dakwahnya yang tertuang dalam QS. Al-An'am [6]: 74-79.

وَإِذْ قَالَ إِبْرَاهِيمُ لَأَبِيهِ عَازَرَ أَتَتَّخِذُ أَصْنَامًا

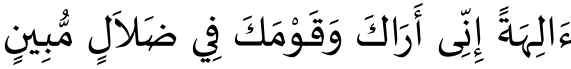

$$
\begin{aligned}
& \text { 774\} وَكَذَلِكَ نُرِي ِإبْرَاهِيمَ مَلَكُوتَ }
\end{aligned}
$$

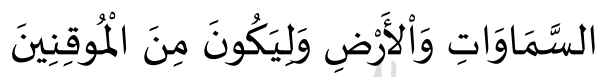

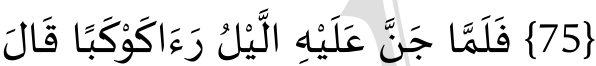

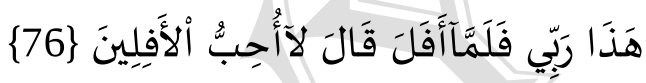

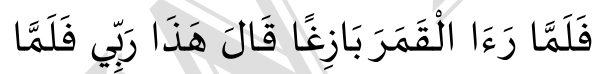

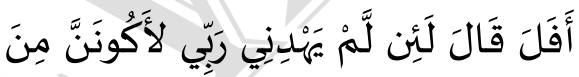

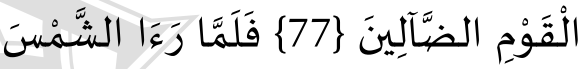

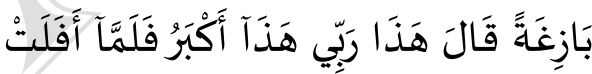

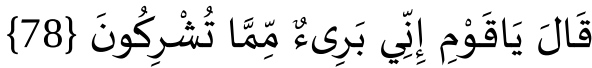
إِنِي وَجَّهْتُ وَجْهِىَ لِلَّذِي فَطَرَ السَّمَاوَاتِ

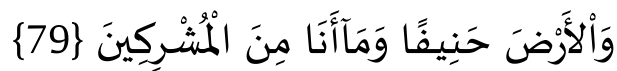

"Dan (ingatlah) di waktu Ibrāhīm berkata kepada bapaknya, Aazar, 'Pantaskah kamu menjadikan berhalaberhala sebagai tuhan-tuhan? Sesungguhnya aku melihat kamu dan kaummu dalam kesesatan yang nyata'. Dan Demikianlah Kami perlihatkan kepada Ibrāhīm tanda-tanda keagungan (kami yang terdapat) di langit dan bumi dan (kami memperlihatkannya) agar Dia Termasuk orang yang yakin. Ketika malam telah gelap, Dia melihat sebuah bintang (lalu) Dia berkata: 'Inilah 'Tuhanku', tetapi tatkala bintang itu tenggelam Dia berkata: 'Saya tidak suka 
kepada yang tenggelam'. Kemudian tatkala Dia melihat bulan terbit Dia berkata: 'Inilah Tuhanku'. tetapi setelah bulan itu terbenam, Dia berkata: 'Sesungguhnya jika Tuhanku tidak memberi petunjuk kepadaku, pastilah aku termasuk orang yang sesat'. Kemudian tatkala ia melihat matahari terbit, Dia berkata: 'Inilah Tuhanku, ini yang lebih besar'. Maka tatkala matahari itu terbenam, Dia berkata: 'Hai kaumku, Sesungguhnya aku berlepas diri dari apa yang kamu persekutukan'.Sesungguhnya aku menghadapkan diriku kepada Rabb yang menciptakan langit dan bumi, dengan cenderung kepada agama yang benar, dan aku bukanlah termasuk orang-orang yang mempersekutukan tuhan".

Menurut Shihab (2002b, hlm. 505) kelompok ayat ini menguraikan sekelumit pengalaman Nabi Ibrāhīm As. "menemukan" Allah Swt., Tuhan Yang Maha Esa. Adapun Quthb (2002, hlm. 145) juga menambahkan bahwa dalam ayat-ayat di atas terdapat panorama yang agung dan menakjubkan, yang tampak dalam hati Nabi Ibrāhīm As., ketika redaksional Alquran menunjukkan pengalaman besar yang telah dilewatinya dalam ayat-ayat yang pendek ini.

Adapun langkah-langkah ilmiah yang dilakukan Nabi Ibrāhīm As. sebagai proses pemikirannya dalam menemukan Allah Swt. adalah sebagai berikut.

\section{a. Merumuskan masalah}

Masalah yang dihadapi Nabi Ibrāhīm As. dalam ayat ini adalah ketika beliau melihat fenomena bahwa ayah dan kaumnya menyembah berhala saat itu dan beliau pun menyatakan kesesatan mereka. Firman Allah Swt.

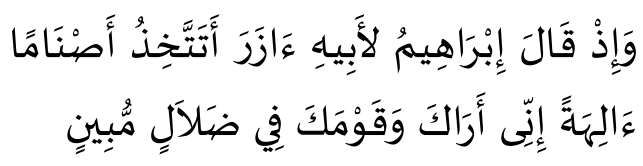
"dan (ingatlah) di waktu Ibrāhīm berkata kepada bapaknya, Aazar, "Pantaskah kamu menjadikan berhalaberhala sebagai tuhan-tuhan? Sesungguhnya aku melihat kamu dan kaummu dalam kesesatan yang nyata" (QS. Al-An'ām [6]:74).

\section{b. Mengumpulkan keterangan}

Setelah mengalami pergolakan batin antara jiwa dan pikirannya, akhirnya Allah Swt. membukakan mata hati Nabi Ibrāhīm As. untuk melihat rahasia-rahasia yang terpendam di alam semesta yang akhirnya mengarahkannya kepada petunjuk-petunjuk kebenaran. Sebagaimana firman Allah Swt:

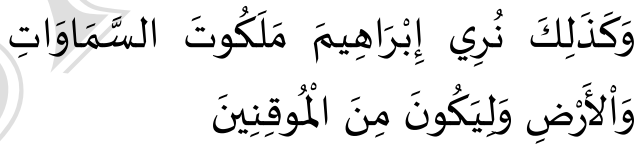

"dan Demikianlah Kami perlihatkan kepada Ibrāhīm tanda-tanda keagungan (kami yang terdapat) di langit dan bumi dan (kami memperlihatkannya) agar Dia termasuk orang yang yakin" (QS. AlAn'ām [6]:75).

\section{c. Menyusun dan menguji hipotesis}

Setelah Nabi Ibrāhīm mendapat petunjuk dari Allah Swt mengenai Ulūhiyyah dan Rububiyyah-Nya Allah dengan menunjukkan kepemilikanNya atas bumi dan langit sebagai hujjah bagi orang-orang musyrik. Kemudian Nabi Ibrāhīm As. (melalui bimbingan Allah Swt) melakukan pendekatan secara bertahap kepada kaumnya atas kebiasaan yang biasa 
mereka lakukan. Hal ini seperti tertera dalam QS. Al-An'am [6]: 76-78.

\section{d. Menarik kesimpulan}

Demikianlah ayat demi ayat Nabi Ibrāhīm As. berargumen dengan kaumnya terkait planet-planet yang mereka jadikan sesembahan selama ini. Beliau merincikan planet dimulai dari yang terkecil cahayanya yaitu bintang sampai dengan yang terbesar cahayanya yaitu bulan sebagai hipotesis untuk menemukan Tuhan sebenarnya yang wajib mereka ibadahi. Hingga akhirnya ia mendapati kesimpulan kebenaran tentang tuhannya, yaitu:

$$
\begin{aligned}
& \text { إِنِي وَجَّهنتُ وَجْهِهَ لِلَّنَيِي فَطَرَ السَّمَاوَاتِ }
\end{aligned}
$$

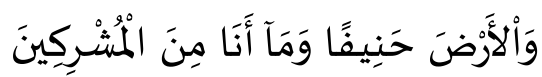

"Sesungguhnya aku menghadapkan diriku kepada Rabb yang menciptakan langit dan bumi, dengan cenderung kepada agama yang benar, dan aku bukanlah Termasuk orang-orang yang mempersekutukan Tuhan" (QS. AlAn'ām [6]:79).

\section{Metode Ḥiwār Jadali (Mujādalah)}

Metode dialog ini sebenarnya sudah dilakukan sejak zaman dahulu. Rasulullah Saw. telah menjadikan metode dialog sebagai pedoman dalam mempraktekkan metode pendidikan dan pengajaran beliau (Syahidin, 2009, hlm. 163).

Dialog merupakan cara yang paling efektif untuk menyampaikan pesan yang dimaksud. Sebagaimana yang dicontohkan oleh dialog yang dilakukan Nabi Ibrāhīm as. dengan Raja Namruż serta para penyembah berhala. Melalui dialog tersebut, Nabi Ibrāhīm as. ingin menyampaikan pesan bahwa penyembahan terhadap berhala yang mereka lakukan selama ini salah dan sesat karena tidak ada yang berhak disembah selain Allah.

Sebagaimana firman Allah dalam QS. Al-Anbiya [21]: 51-70, sebagai berikut:

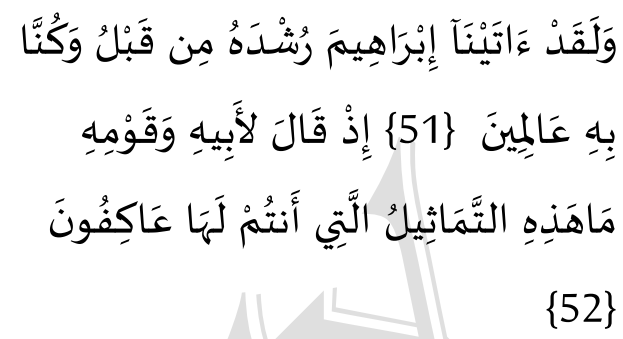

"Dan Sesungguhnya telah Kami anugerahkan kepada Ibrāhīm hidayah kebenaran sebelum (Musa dan Harun), dan adalah Kami mengetahui (keadaan) nya. (Ingatlah), ketika Ibrāhīm berkata kepada bapaknya dan kaumnya: "Patung-patung Apakah ini yang kamu tekun beribadat kepadanya?" (QS. Al-Anbiya [21]: 5152).

Menurut Quthb (2004a, hlm. 70)
ayat ini menjelaskan tentang bagaimana Allah menganugerahi Nabi Ibrāhīm as. dengan petunjuk tauhid atau dalam ayat ini disebut dengan rusyd. Kemudian Shihab (2002d, hlm. 74) memaparkan bahwa kata rusyd makna dasarnya adalah ketepatan dan kelurusan. Kata rusyd bagi manusia artinya kesempurnaan akal dan jiwa yang menjadikannya mampu bersikap dan bertindak setepat mungkin. Penisbahan rusyd kepada Ibrāhīm as., dengan firman-Nya rusydabū hidayahnya, mengandung makna bahwa apa yang dianugerahkan Allah itu adalah satu kekhususan dan keistimewaan tersendiri bagi beliau yang tidak dimiliki orang lain dan 
bahwa hal itu adalah layak untuk beliau.

$$
\text { Pertanyaan yang diajukan }
$$

Ibrāhīm as. kepada bapak dan kaumnya merupakan bukti dari dianugerahkannya petunjuk kepadanya. Al-Maragi (1987c, hlm. 71) menjelaskan bahwa dengan pertanyaan itu, Ibrāhīm as. bermaksud mengingatkan mereka untuk berpikir tentang perkara patung-patung itu, dan menghinakannya sambil berpura-pura tidak mengetahui hakekatnya. Seakan, dengan pertanyaan itu beliau mengisyaratkan, bahwa sekiranya mereka mau berpikir sedikit saja, niscaya mereka mengetahui bahwa batu-batu dan kayu seperti ini tidak memberi manfaat kepada mereka sedikit atau banyak.

Kemudian Shihab (2002d, hlm.

75) menambahkan bahwa pertanyaan yang beliau ajukan itu juga merupakan kecaman terhadap sesembahan mereka serta kecaman terhadap sikap dan perilaku mereka yang demikian tekun menyembahnya. Sikap tegas dan jelas yang ditampilkan oleh Nabi Ibrāhīm as. itu terlihat lebih jelas lagi pada ayatayat berikut.

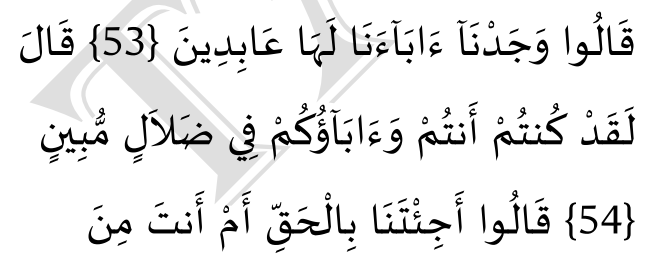

الأَّعبِينَ

"Mereka menjawab: "Kami mendapati bapak-bapak Kami menyembahnya". Ibrāhīm berkata: "Sesungguhnya kamu dan bapak-bapakmu berada dalam kesesatan yang nyata". mereka menjawab: "Apakah kamu datang kepada Kami dengan sungguh- sungguh ataukah kamu termasuk orang-orang yang bermain-main?" (QS. Al-Anbiya [21]:53-55).

Menurut Hamka (1983d, hlm. 59) bahwa dalam ayat 53 ini jawaban yang mereka gunakan itu sungguh pengakuan yang amat lemah. Sebab mereka sendiri pun tidak mengerti apa gunanya berhala-berhala dan patungpatung itu disembah. Cuma mereka dapati bapak-bapak, atau nenekmoyang telah melakukannya juga sejak dulu atau bisa dikatakan telah jadi pusaka turun temurun. Kemudian Quthb (2004a, hlm. 70) menambahkan bahwa jawaban mereka itu menunjukkan kekerasan kepala dan jiwa di dalam lingkaran taklid yang jumud di hadapan kemerdekaan dan kebebasan iman. Iman membebaskan manusia berpikir, merenung, meluruskan segala sesuatu dan norma sengan standar-standar hakiki-bukan standar tradisi dan ikut-ikutan.

Dengan terus terang dan penuh percaya diri Ibrāhīm as. menyadarkan mereka, bahwa perbuatan menyembah dan memuja berhala itu adalah jalan yang sesat (Shihab M. Q., 2002d, hlm. 75). Jawaban Ibrāhīm as. ini mengandung isyarat bahwa yang batil sekali-kali tidak akan pernah menjadi yang haq, sekalipun banyak pemeluknya (Al-Maragi, 1987c, hlm. 73).

Setelah mendengar celaan yang tegas itu dari Nabi Ibrāhīm as., mereka mengeluarkan pertanyaan demikian: Apakah kata-katamu itu sungguhsungguh atau main-main? Menurut Quthb (2004a, hlm. 71) hal itu adalah pertanyaan orang yang akidahnya 
kacau-balau dan tidak pernah merasa tentram dengan pondasinya, karena dia tidak merenungkannya dan tidak mengecek kebenarannya. Orang yang demikian pemikiran dan ruhnya, maka keduanya tidak berfungsi karena dimatikan oleh khurafat dan taklid. Itulah kesesatan yang terjerumus ke dalamnya orang-orang yang tidak berakidah tauhid yang bersih murni, jelas dan lurus dalam akal dan nurani.

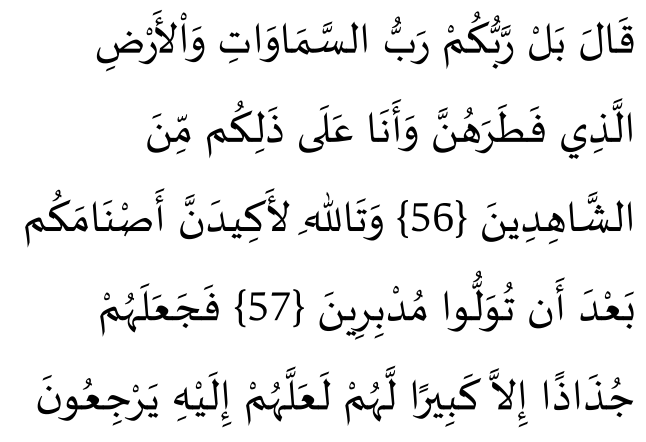

"Ibrāhīm berkata: "Sebenarnya Tuhan kamu ialah Tuhan langit dan bumi yang telah menciptakannya: dan aku Termasuk orang-orang yang dapat memberikan bukti atas yang demikian itu". Demi Allah, Sesungguhnya aku akan melakukan tipu daya terhadap berhala-berhalamu sesudah kamu pergi meninggalkannya. Maka Ibrāhīm membuat berhala-berhala itu hancur berpotong-potong, kecuali yang terbesar (induk) dari patung-patung yang lain; agar mereka kembali (untuk bertanya) kepadanya (QS. Al-Anbiya [21]: 56-58).

Menurut Shihab (2002d, hlm. 77) jawaban Nabi Ibrāhīm as. di atas menampik secara tegas kepercayaan kaum musyikin yang percaya adanya Tuhan Pencipta, di samping tuhantuhan yang berwenang memelihara dan mengurus hal-hal tertentu di alam raya ini. Beliau dalam jawabannya menyatakan bahwa Tuhan adalah Pemelihara langit dan bumi, yakni alam raya seluruhnya, sekaligus Dia yang menciptakannya. Bagi Nabi Ibrāhīm as., setiap wujud yang tampak di alam raya ini berbicara bahwa ia adalah ciptaan Allah dan di bawah kendali serta pengaturan-Nya. Karena itu beliau bersaksi sekaligus bersedia menguraikan bukti-bukti tersebut.

Kemudian Ibrāhīm as. memaklumatkan kepada para penentangnya dalam dialog tersebut, bahwa dia telah berketetapan untuk melakukan suatu perkara terhadap tuhan-tuhan mereka, dan dia tidak akan pernah mundur dari rencana itu (Quthb, 2004a, hlm.71). Lebih lanjut Mujahid dan Qatadah (Al-Maragi, 1987c, hlm.75) berkata bahwa Ibrāhīm as. mengatakan perkataan ini secara sembunyi-sembunyi dari kaumnya, hanya satu orang di antara mereka yang mendengarnya. Lalu, orang itu menyebarkan perkataannya, "Sesungguhnya kami mendengar seorang pemuda menyebut-nyebut mereka. Dia bernama Ibrāhīm".

Adapun menurut Shihab (2002d, hlm.77) sebagian ulama berpendapat bahwa sumpah Nabi Ibrāhīm as. di atas beliau ucapkan di hadapan kaumnya. Menurut mereka, Nabi Ibrāhīm as. pada mulanya berangkat bersama kaumnya untuk menghadiri satu perayaan, lalu di tengah jalan dia mengaku sakit dan kembali ke tempat berhala-berhala itu. Dalam perjalanan pulang itu, beliau bertemu dengan sekelompok orang lemah yang dinilainya tidak berbahaya dan kepada merekalah beliau mengucapkan sumpah itu. Namun menurut 
Țabātabā’i sumpah tersebut tidak diucapkan, tetapi disini ia maksudkan sebagai gambaran tekad yang kuat dari Nabi Ibrāhīm as. untuk melakukan sesuatu terhadap patung-patung itu.

$$
\text { Maka Ibrāhīm as. }
$$

menghancurkan patung-patung itu dan menjadikannya potongan-potongan kecil. Ibrāhīm as. lalu membiarkan berhala yang paling besar agar ketika kaumnya kembali, mereka bisa bertanya kepada berhala ini tentang pelaku perusakan supaya kelemahan dan kesalahan mereka terungkap. Bukti ilmiah yang logis ini dapat menunjukkan kejinya kemusyrikan yang mereka lakukan (Al-Qarni, 2007c, hlm. 20).

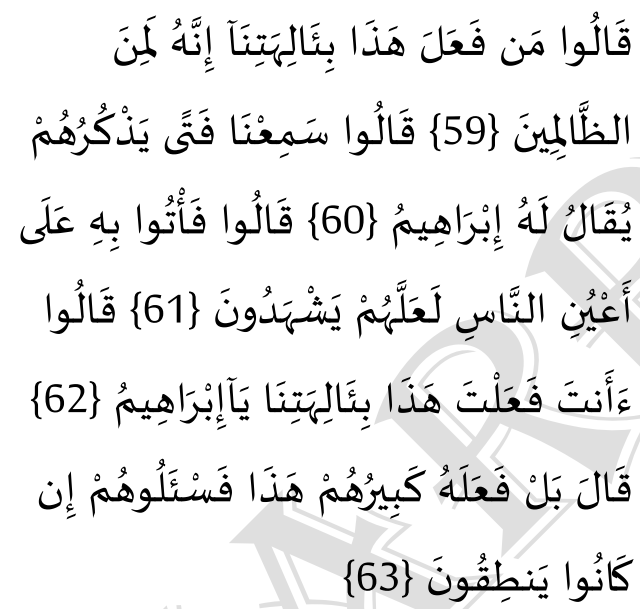

"Mereka berkata: "Siapakah yang melakukan perbuatan ini terhadap tuhan-tuhan kami, Sesungguhnya dia termasuk orang-orang yang zalim." Mereka berkata: "Kami dengar ada seorang pemuda yang mencela berhala-berhala ini yang bernama Ibrāhīm ". Mereka berkata: "(Kalau demikian) bawalah dia dengan cara yang dapat dilihat orang banyak, agar mereka menyaksikan". Mereka bertanya: "Apakah kamu, yang melakukan perbuatan ini terhadap tuhan-tuhan kami, Hai Ibrāhīm?" Ibrāhīm menjawab: "Sebenarnya patung yang besar itulah yang melakukannya, Maka tanyakanlah kepada berhala itu, jika mereka dapat berbicara" (QS. Al-Anbiya [21]: 5963).

Menurut Al-Qarni (2007c, hlm. 21), ketika kaumnya kembali mereka mendapatkan patung-patung mereka telah hancur berkeping-keping. Mereka pun saling bertanya, "Siapakah yang telah berani menhancurkan patung-patung kita? Sesungguhnya dia adalah orang yang keterlaluan dan zalim". Menurut sangkaan mereka, pelaku pengrusakan ini telah menghina keagungan berhala-berhala itu. Di antara mereka yang pernah mendengar Ibrāhīm as. mencaci patung-patung itu pun berkata, "Kami mendengar seorang pemuda yang bernama Ibrāhīm as. mencaci patung-patung ini. Tuduhan ini kuat sekali kaitannya dengannya".

Maka raja Namruż dan orangorang besarnya memerintahkan mencari Nabi Ibrāhīm as. sampai dapat dan membawanya kemari. Membawanya hendaklah disaksikan oleh orang banyak supaya mereka menyaksikan. Sebab kesalahan ini amat besar, sangat menyinggung kepada perasaan orang banyak (Hamka, 1983d, hlm. 63).

Setelah mendatangkan Ibrāhīm as. mereka bertanya: Kamukah yang telah menghancurkan berhala-berhala ini dan menjadikannya berpotongpotong? Mereka meminta agar Ibrāhīm as. mengakui perbuatan itu, supaya mereka dapat menganiayanya dengan meyakini kebenaran tindak kriminil mereka ini. Tetapi, tiba-tiba Ibrāhīm as. mengejutkan mereka 
dengan suatu jawaban, sehingga mereka mencari jalan untuk dapat selamat dari jawaban Ibrāhīm as. yang menyudutkan itu (Al-Maragi, 1987c, hlm. 79). Ibrāhīm as. mempermalukan mereka di hadapan banyak saksi dan memaparkan kedunguan dan kebodohan mereka dengan berkata, "Berhala yang paling besar itulah yang telah menghancurkan patung-patung ini. Oleh karena itu, bertanyalah kepadanya tentang kejadian ini jika memang patung-patung ini hidup dan bisa bicara". Mereka tercengang dan kalah (Al-Qarni, 2007c, hlm. 22).

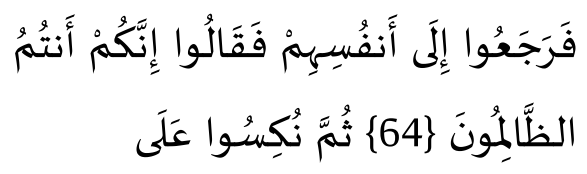

"Maka mereka telah kembali kepada kesadaran dan lalu berkata: "Sesungguhnya kamu sekalian adalah orang-orang yang menganiaya (diri sendiri)". Kemudian kepala mereka jadi tertunduk (lalu berkata): "Sesungguhnya kamu (hai Ibrāhīm) telah mengetahui bahwa berhalaberhala itu tidak dapat berbicara." (QS. Al-Anbiya [21]:64-65).

Menurut Shihab (2002d, hlm. 81), kaum penyembah berhala setelah mendengar jawaban Nabi Ibrāhīm as. itu tercengang, mereka berpikir dan akhirnya sadar bahwa mereka menyembah sesuatu yang tidak berakal, tidak dapat bercakap tidak juga mampu membela diri, lalu sebagian dari mereka berkata, "Sesunggunya bukan Ibrāhīm yang zalim, tetapi kamulah orang yang zalim yang menganiaya diri sendiri dengan menyembah sesuatu yang tidak wajar disembah".

Selanjutnya, Allah menjelaskan bahwa sesudah berkata demikian, mereka berbalik, meninggalkan pikiran yang sehat dan bersih dengan mengakui diri mereka sebagai orang yang zalim, berpindah kepada pikiran yang salah, yaitu menetapkan kebenaran penyembahan terhadap berhala-berhala itu. Padahal, mereka mengakui bahwa keadaannya tidak seperti keadaan bangsa hewan, sehingga tidak patut bagi orang yang berakal untuk menyembahnya (AlMaragi, 1987c, hlm. 81). Adapun menurut Shihab (2002d, hlm. 81), ulama memahami penggalan ayat ini dalam arti mereka memutarbalikkan kebenaran dengan jalan menempatkan kebatilan di tempat kebenaran. Tempat kebenaran adalah di atas (kepala) dan kebatilan berada di bawah (kaki). Dalam konteks ayat ini, mereka menempatkan kebatilan, yakni kezaliman pada sisi Nabi Ibrāhīm as. dan kebenaran pada sisi mereka, padahal yang sebenarnya adalah mereka yang zalim dan Nabi Ibrāhīm as. dalam kebenaran.

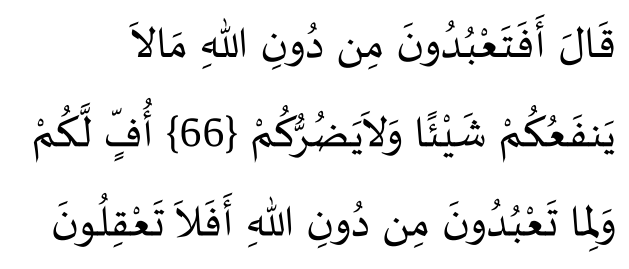

"Ibrāhīm berkata: Maka mengapakah kamu menyembah selain Allah sesuatu yang tidak dapat memberi manfaat sedikitpun dan tidak (pula) memberi mudharat kepada kamu?" Ah (celakalah) kamu dan apa yang kamu sembah selain Allah. Maka Apakah 
kamu tidak memahami?." (QS. AlAnbiya [21]: 66-67).

\section{Ibrāhīm as. menjawab} pernyataan mereka dengan keras dan kasar, bukan seperti kebiasaannya, yaitu bersikap sabar dan lembut. Karena kebodohan mereka disini telah melampaui kesabaran seorang yang paling lembut sekalipun. Namun, pada kondisi demikian keangkuhan telah menguasai mereka disebabkan dosa mereka, sebagaimana para diktator dan țagut-țagut di kuasai oleh keangkuhan mereka ketika sedang terjepit, kehilangan alasan, dan kehabisan dalil. Maka mereka pun terpaksa menggunakan kekuatan yang kejam dan penyiksaan yang keras (Quthb, 2004a, hlm. 73-74).

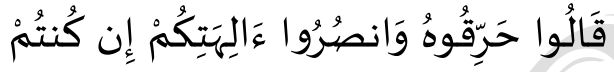

$$
\begin{aligned}
& \text { فَاعِلِينَ } 688 \text { قُلْنَا يَانَارُ كُوني بَرْدًا }
\end{aligned}
$$

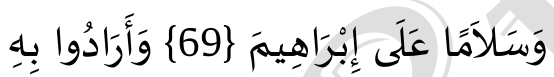

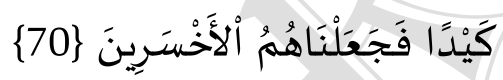

“ Mereka berkata: "Bakarlah dia dan bantulah tuhan-tuhan kamu, jika kamu benar-benar hendak bertindak". Kami berfirman: "Hai api menjadi dinginlah, dan menjadi keselamatanlah bagi Ibrāhīm", Mereka hendak berbuat makar terhadap Ibrāhīm, Maka Kami menjadikan mereka itu orang-orang yang paling merugi." (QS. Al-Anbiya [21]: 68-70).

Menurut Al-Maragi (1987c, hlm. 83) mereka sepakat untuk menghabisi Nabi Ibrāhīm as. Sebagian mereka berkatan kepada sebagian yang lain: Bakarlah Ibrāhīm as. dengan api, dan tolonglah tuhan-tuhan kalian jika benar-benar para penolongnya dan tidak mau membiarkannya, tidak pula mau meninggalkan penyembahan terhadapnya. Maka, mereka pun berbondong-bondong mengumpulkan bahan bakar lalu menyalakannya dan melemparkan Nabi Ibrāhīm as. dengan manjaniq, yaitu semacam ketapel besar, ke tengah kobaran api yang sangat besar. Kemudian Allah Swt. menyelamatkan Nabi Ibrāhīm as. dengan memerintahkan kepada api untuk menjadi dingin dan keselamatan bagi Nabi Ibrāhīm as.

Adapun Shihab (2002d, hlm. 84) mengatakan bahwa dengan pembakaran itu, mereka hendak berbuat makar terhadap Ibrāhīm as., yakni dengan membunuh dan menghabisi ajaran-ajarannya. Oleh karena itu, Allah jadikan mereka itu sebagai orang-orang yang paling merugi. Rugi karena gagal usaha mereka dan rugi pula karena mereka mendapat murka Allah atas ulah mereka itu.

Selain ayat-ayat di atas, metode debat juga diungkapkan dalam ayat lain yaitu QS. Al-Baqarah [2]: 258.

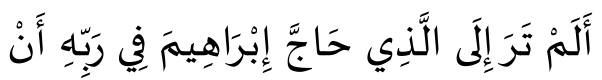

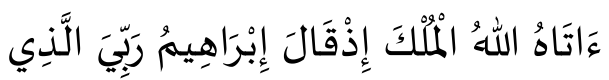

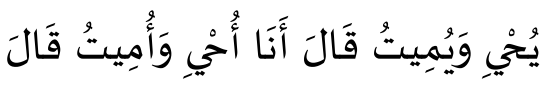

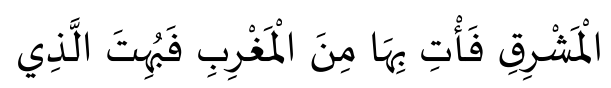

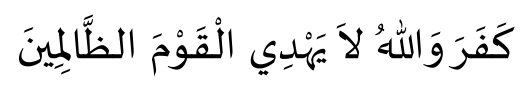

“Apakah kamu tidak memperhatikan orang yang mendebat Ibrāhīm tentang Tuhannya (Allah) karena Allah telah memberikan kepada orang itu pemerintahan (kekuasaan). ketika 
Ibrāhīm mengatakan: "Tuhanku ialah yang menghidupkan dan mematikan," orang itu berkata: "Saya dapat menghidupkan dan mematikan". Ibrāhīm berkata: "Sesungguhnya Allah menerbitkan matahari dari timur, Maka terbitkanlah Dia dari barat," lalu terdiamlah orang kafir itu; dan Allah tidak memberi petunjuk kepada orangorang yang zalim" (QS. Al-Baqarah [2]:258).

Menurut Shihab (2002a, hlm. 674) bahwa kata hājja menunjukkan adanya dua pihak yang saling berdebat. Memang perdebatan itu tidak dapat terjadi sepihak, tetapi karena yang memulai perdebatan adalah penguasa itu, ayat ini mengisyaratkan bahwa dia yang mendebat Ibrāhīm as.

Berdasarkan pemaparan di atas, dapat ditarik kesimpulan bahwa ayatayat di atas menggambaran kehebatan Ibrāhīm as. dalam berdebat atau mengemukakan kebenaran Tuhannya sehingga secara otomatis lawan debat Ibrāhīm as. tidak bisa membantah ucapan-ucapan Ibrāhīm as. karena disertai dengan bujjah dan bukti yang nyata berkenaan dengan sesembahan mereka yang tidak bisa melakukan apaapa. Selain itu, Ibrāhīm as. dalam melakukan debat untuk mendidik umatnya pada nilai-nilai tauhid adalah dengan mengarahkan mereka untuk berpikir.

Kemudian yang menarik dari debat di atas adalah keberanian dan konsistensi Ibrāhīm as. dalam menyampaikan dakwahnya walaupun ia harus berhadapan dengan kebanyakan orang yang menentangnya, sedangkan ia hanyalah seorang diri.

\section{Metode}

Demonstrasi/

\section{Eksperimen}

Metode demonstrasi adalah metode mengajar dengan menggunakan media atau alat peraga untuk menjelaskan suatu konsep atau materi pelajaran tertentu, atau untuk memperlihatkan bagaimana melakukan dan jalannya suatu proses kepada siswa. Jika demonstrasi penekanannya terletak pada memperagakan bagaimana jalannya proses tertentu, maka eksperimen adalah melakukan percobaan atau mempraktikkan secara langsung atau dengan cara meneliti dan mengamati dengan teliti (Fikri, 2011, hlm. 121).

Berdasarkan ayat-ayat yang berkaitan dengan Nabi Ibrāhīm as., penulis menemukan adanya ayat yang membahas mengenai bagaimana Nabi Ibrāhìm as. menguatkan keyakinannya akan keberadaan Tuhan-Nya melalui metode demonstrasi atau eksperimen yang diawali dengan dialog yang dilakukan bersama raja Namrudz. Hal itu dibahas dalam Q.S. Al-Baqarah [2]: 258-260, sebagai berikut:

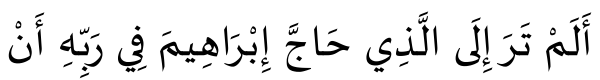

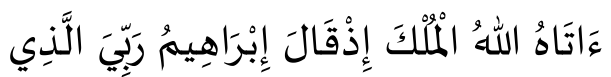

$$
\begin{aligned}
& \text { يُجْيِ وَيُمِيتُ قَالَ أَنَا أُجْي وَأُمِيتُ قَالَ } \\
& \text { إِبْرَاهِيمُ فَإِنَّ اللهَهَ يَأْتِي بِالشَّْمْسِ مِنَ }
\end{aligned}
$$

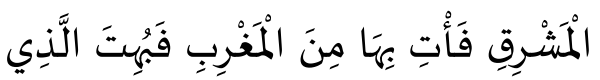

$$
\begin{aligned}
& \text { كَفَرَوَاللَهُ لَا يَهْدِي الْقَوْمَ الظَّالمِينَ }
\end{aligned}
$$


"Apakah kamu tidak memperhatikan orang yang mendebat Ibrāhīm tentang Tuhannya (Allah) karena Allah telah memberikan kepada orang itu pemerintahan (kekuasaan). ketika Ibrāhīm mengatakan: "Tuhanku ialah yang menghidupkan dan mematikan," orang itu berkata: "Saya dapat menghidupkan dan mematikan".Ibrāhīm berkata: "Sesungguhnya Allah menerbitkan matahari dari timur, Maka terbitkanlah Dia dari barat," lalu terdiamlah orang kafir itu; dan Allah tidak memberi petunjuk kepada orang-orang yang zalim (QS. Al-Baqarah [2]: 258).

Menurut Quthb (2000, hlm. 349), ayat pertama mengisahkan dialog antara Nabi Ibrāhīm as. dan seorang raja yang berkuasa pada masanya, yang mendebatnya mengenai Allah Swt. Raja yang mendebat Nabi Ibrāhīm as. itu tidak mengingkari adanya Allah sama sekali. Ia hanya mengingkari kemahaesaan-Nya dalam uluhiyah dan rububiyah, serta kekuasaan-Nya menjaalankan dan mengatur alam semesta ini sendirian.

Kemudian ketika Nabi Ibrāhīm as. mengatakan bahwa Tuhannya dapat menghidupkan dan mematikan. Raja tersebut membantahnya dan mengatakan bahwa dia pun dapat melakukan hal yang sama. Shihab (2002a, hlm. 674) menjelaskan bahwa tentu saja yang dimaksud adalah membatalkan hukuman mati atas seseorang sehingga hidupnya dapat berlanjut dan membunuhnya sampai ia mati. Tapi apa yang dimaksud oleh Nabi Ibrāhīm as. bukanlah seperti itu. Manusia, betapapun kemampuannya, tidak dapat memberi hidup. Di sisi lain, sungguh berbeda hakikat mematikan dengan hakikat membunuh.

Berkaitan dengan jawaban raja tersebut, Nabi pun meneruskan perkataannya yakni dia menantang Raja tersebut untuk melakukan apa yang dilakukan Tuhannya yaitu jika Allah menerbitkan matahari dari barat maka cobalah terbitkan matahari dari barat. Mendengar perkataan tersebut si raja tak bisa menjawab dan hanya terdiam karena memang pada dasarnya si raja tidak mempunyai kemampuan tersebut (Al-Maragi, 1987a, hlm. 39).

Setelah menerangkan mengenai sifat rubübiyah dan ulübiyah Allah, kemudian pembicaraan selanjutnya ini mengungkap misteri kehidupan dan kematian, yaitu:

أَوْ كَالَّنَّي مَرَّ عَلَى قَرْيٍٍَ وَهِيَ خَاوِيَّة عَلَى

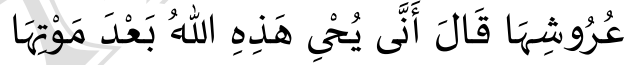

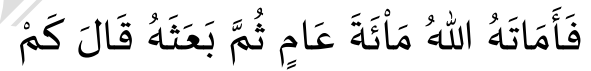
لَبْثَتَ قَالَ لَبْثْتُ يَوْمَا أَوْ بَعْضَ يَوْمِمِ قَالَ

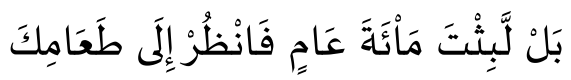

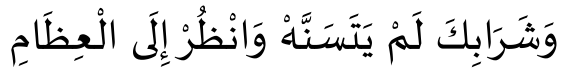

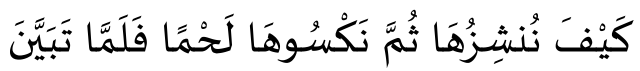

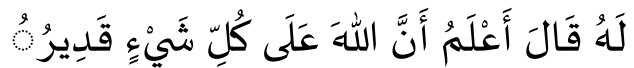
"Atau Apakah (kamu tidak memperhatikan) orang yang melalui suatu negeri yang (temboknya) telah roboh menutupi atapnya. Dia berkata: "Bagaimana Allah menghidupkan kembali negeri ini setelah hancur?" Maka Allah mematikan orang itu seratus tahun, kemudian menghidupkannya kembali. Allah bertanya: "Berapakah lamanya kamu tinggal di sini?" ia menjawab: "Saya tinggal di sini sehari 
atau setengah hari." Allah berfirman: "Sebenarnya kamu telah tinggal di sini seratus tahun lamanya; lihatlah kepada makanan dan minumanmu yang belum lagi berubah; dan lihatlah kepada keledai kamu (yang telah menjadi tulang belulang); Kami akan menjadikan kamu tanda kekuasaan Kami bagi manusia; dan lihatlah kepada tulang belulang keledai itu, kemudian Kami menyusunnya kembali, kemudian Kami membaLuțnya dengan daging." Maka tatkala telah nyata kepadanya (bagaimana Allah menghidupkan yang telah mati) diapun berkata: "Saya yakin bahwa Allah Maha Kuasa atas segala sesuatu" (QS. AlBaqarah [2]:259).

Menurut Quthb (2000, hlm. 352) bahwa ayat ini mengisahkan seseorang yang melewati suatu negeri yang menggambarkan pemandangan tentang kematian, kehancuran, dan tembok yang roboh. Dilukiskan pula guratan perasaan orang orang yang melewati negeri itu. Hingga timbullah pertanyaan, "Bagaimana Allah menghidupkan kembali negeri ini setelah hancur?" Dilukiskannya pemandangan itu seakan-akan sedang membuka mata dan perasaan. Allah tidak menjawab pertanyaan tersebut dengan kalimat tetapi ditunjukkan melalui pengalaman langsung yang bersangkutan. Hujjah tersebut ditunjukkan dengan menjadikan kesadarannya hilang dan tidak bisa bergerak tetapi ruhnya masih ada di dalam tubuhnya. Lalu, Allah membangunkannya setelah melalui masa seratus tahun.

"Berapakah lamanya kamu tinggal di sini?" ia menjawab: "Saya tinggal di sini sehari atau setengah hari."Adapun Al-Maragi (1987a, hlm.

44) mengemukakan bahwasanya maksud dari pertanyaan tersebut karena di dalam hatinya ada perasaan yang menduga akan ketidakmampuan Allah Swt. melakukan hal yang demikian. Karenanya lalu diperlihatkan padanya kehebatan kekuasaan Allah Swt. dengan membiarkan makanan dan minuman tidak mengalami kerusakan, meski telah melewati waktu yang sangat panjang. Hal ini sekaligus membritahukan bahwa dihidupkannya kembali itu adalah setelah melalui masa yang sangat panjang. Dengan demikian, keraguan itu hilang setelah melihat kehebatan kekuasaan Allah swt.

Ayat selanjutnya juga merupakan pembuktian mengenai kekuasaan Allah Swt dalam menghidupkan dan mematikan ditunjukkan melalui metode ekperimen, yaitu:

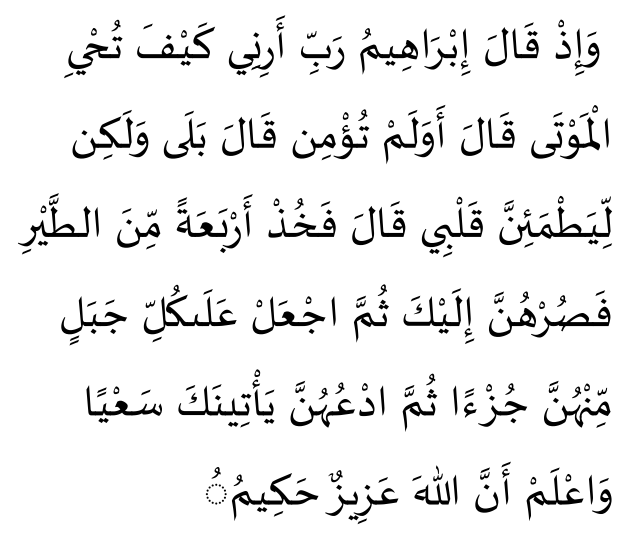

"Dan (ingatlah) ketika Ibrāhīm berkata: "Ya Tuhanku, perlihatkanlah kepadaku bagaimana Engkau menghidupkan orang-orang mati." Allah berfirman: "Belum yakinkah kamu ?" Ibrāhīm menjawab: "Aku telah meyakinkannya, akan tetapi agar hatiku tetap mantap (dengan

TARBAWY: Indonesian Journal of Islamic Education - Vol. 4 No. 2 (2017) | 100 
imanku) Allah berfirman: "(Kalau demikian) ambillah empat ekor burung, lalu cincanglah semuanya olehmu. (Allah berfirman): "Lalu letakkan diatas tiap-tiap satu bukit satu bagian dari bagian-bagian itu, kemudian panggillah mereka, niscaya mereka datang kepadamu dengan segera." dan ketahuilah bahwa Allah Maha Perkasa lagi Maha Bijaksana (QS. Al-Baqarah [2]: 260).

Menurut Al-Qarni (2007a, hlm. 207) ayat ini menjelaskan tentang permohonan Nabi Ibrāhīm as kepada Rabb-Nya agar Dia memperlihatkannya cara menghidupkan orang-orang yang telah mati. Permintaan tersebut ia lakukan bukan karena ia tidak meyakini kekuasaannya Allah Swt., akan tetapi ia hanya ingin menyaksikan prosesnya juga untuk membuatnya semakin yakin. Adapun menurut Hamka (1983a, hlm. 36) pertanyaan itu bermaksud bahwa Nabi Ibrāhīm as ingin menambah pengetahuannya. Dia ingin kenaikan derajat imannya daripada ilm AlYaqin menjadi 'Ain Al-Yaqin.

Allah menyuruh Nabi Ibrāhīm as. memilih empat ekor burung, lalu dia memeliharanya dan menjinakannya. Kemudian dia diperintahkan untuk menyembelih dan memotong-motong dagingnya serta mengacaknya. Lalu membaginya menjadi empat bagian dan menaruh tiap-tiap bagian ke sebuha bukit yang terpisah. Setelah itu dia memanggil mereka. Maka, menyatu kembalilah bagian-bagian itu pada masing-masingnya dan hidup kembali, kemudian terbang kembali kepadanya memenuhi panggilannya (Quthb, 2000, hlm. 355). Konon sebagaimana yang dijelaskan dalam Shihab (2002a, hlm. 682) bahwa empat jenis ekor burung yang dimaksud dalam ayat ini adalah gagak, merak, ayam jantan, dan elang, atau yang terakhir adalah merpati.

Lebih lanjut, Shihab (2002a, hlm. 683) menjelaskan bahwa kisah Nabi Ibrāhīm as. sebagai manusia biasa memanggilnya, tidak mungkin unggas atau burung-burung itu akan datang. Karena manusia biasa tidak dapat menghidupkan yang mati. Tetapi ketika itu, qudrat Allah dianugerahkan sebagian kepada beliau sebagai makhluk yang dicintaiNya, sehingga terjadilah seperti yang diuraikan ayat ini. Hal itu sesuai dengan hadis bahwa:

"Hamba-Ku akan terus menerus mendekatkan diri kepada-Ku sehingga Aku mencintainya, dan bila Aku mencntainya, jadilah Aku pendengarannya yang dia gunakan mendengar, penglihatannya yang dia gunakan melihat, tangannya yang dia gunakan menghajar, dan kakinya yang dia gunakan berjalan" (HR. Bukhārī melalui Abu Hurairah)

Berdasarkan pemaparan di atas, penulis menemukan bahwa Nabi Ibrāhīm as dalam rangka menyampaikan misi ketauhidannya, melalui beberapa tahap yaitu dimulai berdialog dengan Raja Namruż, kemudian dilanjutkan dengan pengalaman hingga metode eksperimen/ demonstrasi tentang bagaimana Allah dengan kekuasanNya dan kehebatan-Nya 
menghidupkan dan mematikan makhluk-Nya.

\section{Metode Keteladanan}

Yang dimaksud metode keteladanan disini yaitu suatu metode pendidikan dengan cara memberikan contoh yang baik kepada peserta didik, baik dalam ucapan maupun perbuatan(Syahidin, 2009, hlm. 150). Sebagaimana firman Allah Swt. dalam QS. Al-Mumtahanahah [60]: 4-6.

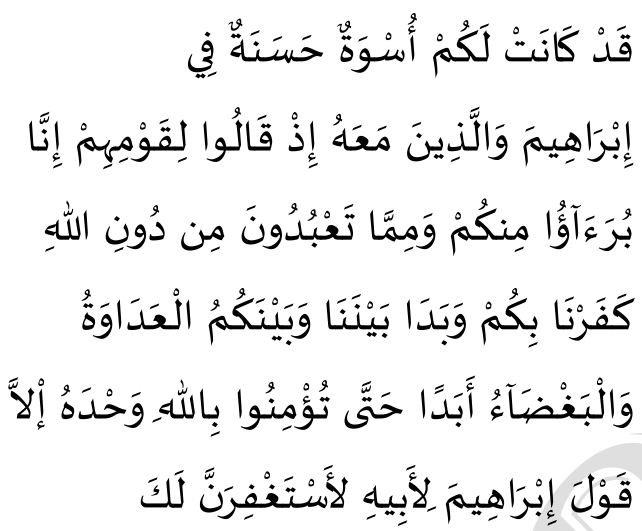

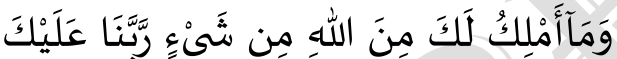

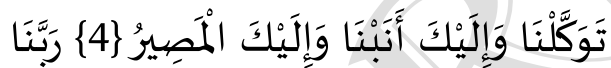

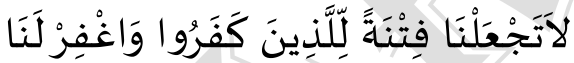

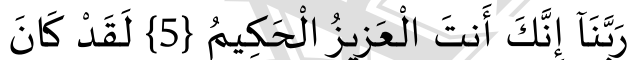

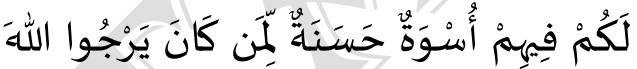
وَالْيَوْمَ الْالَخِخرَوَمَنَ يَتَوَلَّ فَإِنَّ اللَهَهَ هُوَ الْغَنِيُّ

الْحَمِيدُ ك\}

"Sesungguhnya telah ada suri tauladan yang baik bagimu pada Ibrāhīm dan orang-orang yang bersama dengan dia; ketika mereka berkata kepada kaum mereka: "Sesungguhnya Kami berlepas diri daripada kamu dari daripada apa yang kamu sembah selain Allah, Kami ingkari (kekafiran) mu dan telah nyata antara Kami dan kamu permusuhan dan kebencian buat selama-lamanya sampai kamu beriman kepada Allah saja. kecuali Perkataan Ibrāhīm kepada bapaknya: "Sesungguhnya aku akan memohonkan ampunan bagi kamu dan aku tiada dapat menolak sesuatupun dari kamu (siksaan) Allah". (Ibrāhīm berkata): "Ya Tuhan Kami hanya kepada Engkaulah Kami bertawakkal dan hanya kepada Engkaulah Kami bertaubat dan hanya kepada Engkaulah Kami kembali". "Ya Tuhan Kami, janganlah Engkau jadikan Kami (sasaran) fitnah bagi orang-orang kafir. dan ampunilah Kami Ya Tuhan kami. Sesungguhnya Engkaulah yang Maha Perkasa lagi Maha Bijaksana".Sesungguhnya pada mereka itu (Ibrāhīm dan umatnya) ada teladan yang baik bagimu; (yaitu) bagi orang-orang yang mengharap (pahala) Allah dan (keselamatan pada) hari kemudian. dan Barangsiapa yang berpaling, Maka Sesungguhnya Allah Dia-lah yang Maha Kaya lagi Maha Terpuji (QS. Al-Mumtahanah [60]:46).

Menurut Hamka (1985, hlm. 97), ayat keempat, kelima dan keenam ini menunjukkan suri tauladan Nabi Ibrāhīm as. untuk dijadikan contoh. Agama yang dibangkitkan kembali oleh Nabi Muhammad Saw. ialah agama Hanīfan Musliman, yang bertujuan lurus kepada Allah disertai penyerahan diri. Dalam perjuangan beliau menegakkan agama Allah tidaklah sedikit hambatan, rintangan dan halangan yang beliau temui dengan kaumnya, namun segala gangguan itu tidaklah membuat beliau berkisar dan beranjak pergi dari pendiriannya.

Dalam ayat keempat dikemukakan bahwa pada diri Ibrāhīm as. dan para pengikutnya terdapat suri

TARBAWY: Indonesian Journal of Islamic Education - Vol. 4 No. 2 (2017) | 
tauladan bagi kalian. Yakni ketika mereka berlepas diri dari kaum mereka yang kafir dan dari penyembahan mereka kepada selain Allah. Ibrāhīm as. dan para pengikutnya sangat mengingkari perbuatan mereka dan menampakkan permusuhan kepada mereka, baik secara lisan maupun perbuatan, juga membenci dalam hati selama mereka terus menerus dalam kekafiran sampai mereka mengesakan Allah dalam ibadah (Al-Qarni, 2007d, hlm. 326).

Kemudian Al-Maragi (1987d, hlm. 107) menambahkan bahwa ada pengecualian yang tidak perlu diteladani, yaitu permohonan ampun dari Ibrāhīm as. untuk bapaknya, sebab permohonan ampun untuk bapaknya itu adalah karena suatu janji yang dijanjikan kepada bapaknya. Tetapi setelah jelas baginya bahwa bapaknya itu musuh Allah, dia berlepas diri darinya.

Dengan demikian, ayat-ayat tersebut menjelaskan bahwa dalam dunia pendidikan, pendidik merupakan salah satu aspek yang paling penting. Hal ini dikarenakan seorang pendidik akan menjadi figur bagi peserta didik. Maka dari itu, menjadi seorang teladan yang baik adalah tugas bagi seorang pendidik.

\section{IMPLIKASI TERHADAP PEM- BELAJARAN PAI}

Berdasarkan analisis terhadap kisah-kisah Nabi Ibrāhīm As. dapat diketahui bahwasanya ayat-ayat tersebut mengemukakan berbagai macam metode yang digunakan Nabi Ibrāhīm As. untuk menyeru atau mendidik kaumnya kepada ajaran tauhid. Metode yang dilakukan Nabi Ibrāhīm As. sebagaimana yang tercantum dalam Alquran itu akan senantiasa berkembang seiring perkembangan zaman dan akan terus berlaku hingga akhir zaman, itulah sebabnya Alquran disebut sebagai kitab suci yang abadi. Alquran merupakan petunjuk bagi setiap permasalahan hidup yang dialami manusia. Begitu juga dengan pendidikan. Alquran, baik secara tersurat maupun tersirat selalu dapat memberikan solusi tentang bagaimana seharusnya pendidikan itu dilaksanakan.

Adapun kisah-kisah Nabi Ibrāhīm As. yang dianalisis adalah sebagai berikut, yaitu QS. Maryam [19]: 41-48, QS. Al-An'am [6]: 74-79, QS. Al-Anbiya [21]: 51-70, QS. AlBaqarah [2]: 258-260 dan QS. AlMumtahanah [60]: 4-6. Dari hasil analisis, ayat-ayat tersebut memiliki implikasi terhadap proses pembelajaran Pendidikan Agama Islam, khususnya dalam penggunaan metode pembelajaran di sekolah. Adapun implikasi tersebut kemudian dijelaskan dalam uraian berikut.

\section{Metode Intuitif}

Penggunaan metode intuitif ini dapat diterapkan dalam pembelajaran, salah satu contohnya adalah memulai dan mengakhiri pembelajaran dengan berdoa. Apabila dikaitkan dengan pendidikan tauhid, maka berdo'a merupakan salah satu cara menanamkan ketauhidan kepada peserta didik dengan kalimat-kalimat yang ada dalam do'a tersebut. Hal 
tersebut dapat berpengaruh terhadap jiwanya yang menyadari bahwa segala kehidupannya hanya boleh bergantung kepada Allah dan akan berpengaruh terhadap perkembangannya di masa yang akan datang.

\section{Metode Rasional}

Penggunaan metode rasional dalam pembelajaran ini tujuannya adalah agar pendidik dapat membentuk kepribadian peserta didik dengan cara memberikan pemahaman yang benar dan tepat tentang sesuatu. Dalam penggunaan metode rasional ini, pendidik diharapkan mampu menumbuhkan sikap kritis dan peka terhadap suatu permasalahan dalam diri peserta didik. Dengan begitu, peran akal peserta didik dalam memahami dan menerima sebuah materi ajar dapat berfungsi secara optimal. Maka pembelajaran dengan metode ini dapat dilakukan dengan mengadakan sistem tanya jawab, diskusi, kerja kelompok dan latihan.

\section{Metode Targīb wa Tarhīb}

Menurut Syahidin (2009, hlm.

127) penggunaan metode targib-tarhib didasarkan pada asumsi bahwa tingkat kesadaran manusia itu berbeda-beda, ada orang yang sadar hanya melalui nasihat atau teladan baik, tetapi ada juga yang tidak bisa tersadarkan kecuali hanya dengan ancaman.

Salah satu contoh dalam pembelajaran tauhid ialah ketika pendidik membahas tentang rukun iman, yaitu iman kepada Allah. Pertama-tama pendidik memberikan pemahaman terlebih dahulu kepada peserta didik tentang iman kepada Allah Swt., lalu kemudian dampak yang ditimbulkan dari orang yang beriman kepada Allah Swt dan orang yang tidak mengimani-Nya. Hal itu dapat dilakukan melalui diskusi ringan antar peserta didik di dalam kelas dan guru bertindak sebagai fasilitatornya.

\section{Metode Ibrah Maw'izah}

Penggunaan metode ibrah maw'izah sama halnya dengan metode lain, ia akan menjadi alat yang tepat manakala dibawakan oleh pendidik yang tahu bagaimana menggunakannya dan dalam situasi yang cocok, baik materi yang dibawakan, tujuan yang dikehendaki, maupun waktu yang dipilih.

Salah satu contoh penggunaan metode ibrah mauizah ini bila dikaitkan dengan pendidikan tauhid adalah menceritakan bagaimana kisahkisah yang terdapat dalam Alquran yang tidak mau mengakui keesaan Allah, sekalipun telah datang kepada mereka petunjuk ketauhidan itu melalui para Nabi Allah, misalnya yaitu kisah Fir'aun, dsb.

\section{Metode Ilmiah}

Penerapan metode ilmiah dalam pembelajaran tidak hanya fokus pada bagaimana mengembangkan kompetensi siswa dalam melakukan observasi atau eksperimen, namun bagaimana mengembangkan pengetahuan dan keterampilan berpikir sehingga dapat mendukung aktivitas kreatif dalam berinovasi dan berkarya.

Metode ilmiah merupakan teknik merumuskan pertanyaan dan menjawab pertanyaan melalui kegiatan 
observasi, mencoba melaksanakan aktivitas, atau melaksanakan percobaan. Misalnya dengan mendiskusikan sifat wujud Allah di dalam kelas bersama peserta didik, dan pendidik bertindak sebagai fasilitator.

\section{Metode Hiwār Jadali (Mujādalah)}

Penggunaan metode Hiwār dalam pendidikan tauhid, bisa diterapkan melalui diskusi dalam kelas mengenai penciptaan alam ini beserta seluruh isinya berdasarkan sifat-sifat wajib bagi Allah.

\section{Metode Demonstrasi/ Eksperimen}

Dalam penggunnaannya, metode ini bertujuan agar peserta didik dapat memahami materi dengan lebih mudah karena pembelajaran disajikan dalam bentuk konkrit. Dengan begitu, peserta didik memiliki pengetahuan, pengalaman dan pengertian yang lebih jelas.

Penggunaan metode demonstrasi/eksperimen ini dapat pendidik terapkan ke dalam materi pembelajaran tauhid, contohnya yaitu dengan mengajak peserta didiknya untuk belajar di alam, kemudian peserta didik diarahkan untuk melihat keadaan alam sekitar dan mentafakekuri penciptaan alam semesta beserta seluruh isinya tersebut. Tidak ada yang bisa menciptakan selain Allah Swt.

\section{Metode Keteladanan}

Salah satu contoh penggunaan metode keteladanan ini dalam upaya menanamkan nilai-nilai ketauhidan adalah guru membiasakan salat disiplin tepat pada waktunya, berakhlak mulia. Hal tersebut secara tidak langsung menunjukkan bahwa pendidik memiliki jiwa ketauhidan yang hanya takut dan tunduk kepada Allah Swt. kemudian muncul dalam setiap aktivitasnya sehari-hari.

\section{KESIMPULAN}

Ibrāhīm as lahir di Kota Ur sekitar tahun 1978 SM. Kota ini berada di tepi selatan sungai Furat, sekitar 150 kilometer sebelah barat Bașrah. Allah Swt. telah memilih Nabi Ibrāhīm as. sebagai nabi dan rasul-Nya dengan tugas suci mengeluarkan kaumnya dari kesesatan. Keluarganya sendiri adalah pihak pertama yang diserunya kepada ajaran tauhid, yaitu Āzar, ayah Nabi Ibrāhīm as. Namun ajakan Nabi Ibrāhīm as. tersebut mendapat penolakan dari ayahnya. Penolakan juga terjadi ketika Nabi Ibrāhīm as. menyeru kaumnya untuk menyembah kepada Allah. Bahkan penolakan itu berujung kepada dibakarnya Nabi Ibrāhīm as. dalam kobaran api yang sangat besar atas perintah seorang Raja, namun Allah menyelamatkan Nabi Ibrāhīm as. dari api tersebut. Berbagai cobaan dan rintangan yang dihadapi Nabi Ibrāhīm as. tersebut tidak pernah menyurutkan tekadnya dan membuatnya putus asa dalam menyerukan ajaran tauhid kepada kaumnya.

Di dalam kisah Nabi Ibrāhīm As. ini ditemukan bahwa untuk melancarkan misinya menyampaikan ajaran tauhid kepada kaumnya, Nabi Ibrāhīm As. melakukan berbagai cara agar kaumnya mau mengikuti 
ajarannya dan melepaskan diri mereka dari kemusyrikan. Adapun metode dan pendekatan yang dilakukan Nabi Ibrāhīm as, yaitu: metode intuitif, metode rasional, metode Targib wa Tarbib, metode Ibrah Maw'ịah, metode ilmiah, metode Hiwār Jadali, metode demonstrasi/eksperimen, dan metode keteladanan.

Implikasi dari metode pendidikan tauhid yang terdapat dalam kisah Ibrāhīm As. terhadap pembelajaran PAI di sekolah, khususnya penggunaan metodemetode tersebut dalam pembelajaran PAI yaitu bahwasanya metode pendidikan tauhid tersebut memiliki implikasi edukatif terhadap metode pembelajaran PAI di sekolah, khususnya pembelajaran tauhid.

\section{REFERENSI}

Al-Syarif, S., \& Manshur, F. M. (2017). Metode Pendidikan Profetik dalam Al-Qur'an: Kajian AyatAyat Kisah Nabi Ibrahim As. Jurnal Penelitian Pendidikan Islam, 5, 2-16.

Asmuni, M. Y. (1993). Ilmu Taubid. Jakarta: PT Raja Grafindo Persada.

Constantin. (2012). Urgensi Pendidikan Tauhid dalam Keluarga. Jurnal Pendidikan Agama Islam; At-ta'lim Vol.3 , 97100.

Daradjat, Z. (2004). Ilmu Pendidikan Islam (5 ed.). Jakarta: Bumi Aksara.

Fikri, M. (2011). Konsep Pendidikan Islam; Pendekatan Metode
Pengajaran. Jurnal Ilmiah Islam Futura, XI, 119.

Hanafi, A. (1995). Pengantar Teologi Islam. Jakarta: Al-Husna Zikra.

Harahap, I. (2013). Ibrabim As. Bapak Semua Agama: Sebuah Rekonstruksi Sejarah Kenabian Ibrabim As. Sebagaimana Tertuang dalam Taurat, Injil dan Al-Qur'an. Tengerang: Lentera Hati.

Majid, A. (2012). Belajar dan Pembelajaran Pendidikan Agama Islam. Bandung: PT Remaja Rosdakarya.

Minarti, S. (2013). Ilmu Pendidikan Islam: Fakta Teoretis-Filosofis \& Aplikatif-Normatif. Jakarta: Amzah.

Muhaimin, Suti'ah, \& Ali, N. (2001). Paradigma Pendidikan Islam. Bandung: PT Remaja Rosdakarya.

Qomar, M. (2005). Epistemologi Pendidikan Islam Dari Metode Rasional Hingga Metode Kritik. Jakarta: Erlangga.

Quthb, S. (2002). Tafsir Fi Zbilalil Qur'an di bawah naungan AlQur'an (Vol. 4). (A. Yasin, Penerj.) Jakarta: Gema Insani Press.

Shihab, M. Q. (2002). Tafsir AlMishbah: Pesan, Kesan dan Keserasian Al-Qur'an. Jakarta: Lentera Hati.

Siddik, H. (2012). Metode Pendidikan Tauhid Nabi Ibrahim As dalam Al-Qur'an. Al-Riwayah, 5.

Syahidin. (2009). Menelusuri Metode Pendidikan dalam Al-Quran. Bandung: Alfabeta. 
Tafsir, A. (2009). Filsafat Ilmu.

Bandung: PT. Remaja

Rosdakarya.

TARBAWY: Indonesian Journal of Islamic Education - Vol. 4 No. 2 (2017) | 107 